\section{Supercooling Strawberry Plants Inoculated with Ice-nucleation-active Bacteria and Treated with Frostgard}

\author{
Jeffrey A. Anderson and Julia Whitworth ${ }^{1}$ \\ Department of Horticulture and Landscape Architecture, Oklahoma State \\ University, Stillwater, OK 74078
}

Additional index words. Fragaria $\times$ ananassa, freezing properties, frost

\begin{abstract}
Frostgard did not effectively promote the supercooling of flowering 'Arking' strawberry (Fragaria $\times$ ananassa Duch.) plants in the presence or absence of ice-nucleation-active bacteria when applied as a spray in laboratory experiments. Frostgard effectively promoted supercooling and reduced the ice propagation rate of aqueous solutions. Detached leaves infiltrated with Frostgard exhibited a negative linear relationship between freezing temperature and Frostgard concentrations from $0 \%$ to $20 \%$ (by volume). Leaves infiltrated with $20 \%$ Frostgard supercooled $1.7 \mathrm{C}$ lower than those infiltrated with distilled water. Ice propagation barriers in strawberry plants were observed. Individual leaves froze independently, and a thermal ice propagation barrier sometimes was observed at the crown.
\end{abstract}

Freeze damage to plants results in enormous losses of revenue, labor, fuel, and materials. Estimates of annual losses due to lowtemperature injury in the U.S. range from $\$ 500$ million for the citrus industry (Yelenosky and Young, 198 1) to nearly $\$ 1$ billion for all crops (White and Haas, 1975). Many traditional frost protection methods have become cost-prohibitive or are not suited to all crop systems. Irrigation has protected some crops effectively (Buchanan et al., 1982; Locascio et al., 1967; Wilcox and Davies, 1981); however, windy conditions or poorly drained soils can limit its usefulness (Parsons and Tucker, 1984). Low-cost, alternative methods of reducing frost damage are needed to protect crops from late spring freezes.

One such method is supercooling. Rather than supplying energy to maintain plant temperatures higher than the critical freezing range, passive methods allow plants to approach thermal equilibrium with the surrounding air. Freezing is avoided by reducing the number, efficiency, or both, of ice-nucleating agents. Certain bacterial genotypes are effective ice nucleators (Lindow et al., 1978a; Maki et al., 1974; Paulin and Luisetti, 1978). Ice-nucleation-active (INA) bacteria limited the super-

Received for publication 1 Oct. 1992. Accepted for publication 25 Mar. 1993. Oklahoma Agricultural Experiment Station (OAES) publication 6318. We gratefully acknowledge the assistance of Glenn Drown. This study was supported in part by the OAES and a grant from the North American Strawberry Growers Association. Mention of a trademark, proprietary product, or vendor does not constitute a guarantee or warranty of the product and does not imply its approval to the exclusion of other products or vendors that also maybe suitable. The cost of publishing this paper was defrayed in part by the payment of page charges. Under postal regulations, this paper therefore must be hereby marked advertisement solely to indicate this fact.

'Wes Watkins Agricultural Research Station, Lane, OK 74555 . cooling of small plants and plant parts when present in sufficient numbers (Lindow, 1983b; Proebsting et al., 1982). Frost protection based on controlling populations of INA bacteria or negating their capacity to trigger freezing has been proposed. Reduced frost damage after introducing competitive (non-INA) bacteria (Lindow et al., 1978b) and various nucleationinhibiting compounds (Lindow, 1983a) was reported. However, compounds that effectively reduced bacterial ice nucleation were toxic (Lindow, 1983a). Evaluations of several cryoprotectants and antitranspirants indicated that no significant frost protection was achieved (Hummel and Teets, 1986; Perry et al., 1992; Rieger and Krewer, 1988). Frostgard (Custom Chemicides, Fresno, Calif.) is another commercially available product purported to reduce frost damage to some crops, including strawberry. Literature on Frostgard indicates that the product inhibits bacterial ice nucleation and acts as a cryoprotectant after being absorbed by the plant. Lindemann and Suslow (1987) reported that detached strawberry flowers harboring INA bacteria froze at $\approx 3 \mathrm{C}$ higher than noninoculated flowers. characterized in peach [Prunus persica (L.) Batsch] shoots and flowers (Anderson and Smith, 1989), potted citrus [Citrus sinensis (L.) and C. jambhiri Lush] plants (Yelenosky, 1991), and field-grown nectarine [Prunus persica (L.) Batsch] trees (Ashworth et al., 1985). No ice propagation barriers were observed. The rosette architecture of strawberry plants may result in unusual freezing behavior compared with that of previously studied plants due to the thermal buffering that results from the crown's contact with the soil. If the linear advance of ice formation must pass through a crown that is at a higher temperature than exposed leaves and flowers, a thermal barrier to ice propagation could exist. Our primary objective was to determine whether the supercooling of strawberry plants could be increased
Ice nucleation and propagation have been significantly by Frostgard. We believed that at least $2 \mathrm{C}$ of protection would be necessary to be of practical importance. Preliminary studies were conducted to determine the effects of Frostgard on supercooling and ice propagation rate of aqueous solutions. Laboratory experiments -were conducted to evaluate the efficacy of Frostgard on strawberry plants in the presence and absence of detectable levels of INA bacteria. Another objective was to characterize ice nucleation and propagation in strawberry plants.

Freezing aqueous solutions. The effect of Frostgard on supercooling aqueous solutions was determined by cooling test tubes containing $3 \mathrm{ml}$ of liquid. Treatments included $0 \%$, $0.1 \%, 1 \%, 5 \%, 10 \%$, and $20 \%$ (by volume) Frostgard. Tubes were cooled at $1 \mathrm{C} / \mathrm{b}$ in a refrigerated bath (model EX-400DD bath, EN850 flow-through cooler, ETP-3 temperature programmer; Neslabs Instruments, Portsmouth, N.H.), and freezing was detected from thermal analyses generated by thermocouples taped to the outside of each tube. Ten tubes per concentration were assayed on each of six dates. Freezing rates were determined by filling 10-ml glass pipettes with Frostgard solutions and plugging the tip with wax. The cotton plug in the other end of the pipette was saturated with a suspension of INA bacteria before being sealed with wax. INA bacteria prevented extensive supercooling and allowed freezing rates to be determined at similar temperatures $(-3.5 \pm 1.1 \mathrm{C})$. Freezing rate is a function of freezing temperature, and higher rates are observed with increased supercooling (Yelenosky and Horanic, 1969). Thermocouples were taped to each end (25 cm apart) and the center of the pipette before the pipettes were suspended horizontally in a low-temperature chamber (model CEC23; Rheem Scientific, Asheville, N.C.). Chamber temperature was equilibrated at $-2 \mathrm{C}$, then decreased $0.5 \mathrm{C} / \mathrm{h}$. Temperatures were monitored every 5 sec with a datalogger (model 21X, Campbell Scientific, Logan, Utah). Three pipettes per concentration were assayed on each of three dates.

Freezing whole plants. Dormant strawberry plants were kept in vented plastic bags containing damp toweling in a refrigerator at $\approx 5 \mathrm{C}$. To produce a continuous supply of flowering plants, groups of 10 plants were removed periodically from the refrigerator, placed in peat pots containing commercial mix, and grown in a growth chamber at $22 / 18 \mathrm{C}$ day/ night for 21 to 28 days. A photosynthetic photon flux of $\approx 500 \mu \mathrm{mol} \cdot \mathrm{m}^{-2} \cdot \mathrm{s}^{-1}$ at canopy height was maintained during a 14-h photoperiod. Plants were fertilized at each watering with $0.75 \mathrm{~g} 20 \mathrm{~N}-9 \mathrm{P}-17 \mathrm{~K}$ soluble fertilizer per liter. Bacterial cultures were grown as previously described by Anderson et al. (1982). Eight uniform, flowering plants were sprayinoculated with sterile water (control) or a $10^{6}$ cells $/ \mathrm{ml}$ suspension of Erwinia herbicola (Lohnis) Dye isolate 478AR53 on each date the experiment was repeated. This bacterium is a spontaneous mutant with resistance to 3[(4-methyl-1-piperazinyl)iminomethyl] (rifampicin) at $100 \mu \mathrm{g} \cdot \mathrm{ml}^{-1}$. Plants were inocu- 
lated with a chromatography sprayer that deposited $\approx 2 \mathrm{ml}$ of bacterial suspension or sterile water on each plant. Plants were kept in a growth chamber for $24 \mathrm{~h}$ after inoculation to allow bacterial populations to stabilize. Frostgard ( $10 \%$ by volume) was applied with a chromatography sprayer that deposited $\approx 2$ $\mathrm{ml} / \mathrm{plant} 48 \mathrm{~h}$ before freezing assays.

Plant freezing temperatures were determined as described previously using 0.1-mmdiameter thermocouples (Anderson and Smith, 1989). On each strawberry plant, freezing temperatures of two leaf petioles, one inflorescence pedicel, and the crown were measured. Crown temperature was monitored by placing the thermocouple junction in contact with the tissue at the base of a leaf axil and taping the wire to a petiole. Some plants had two growing points from the crown and both were monitored. Plants were placed in a programmable low-temperature chamber after the pots were insulated with vermiculite to delay soil freezing. The soil froze after the plants in all cases. The chamber was equilibrated at $\mathrm{O}$, then decreased $1 \mathrm{C} / \mathrm{h}$ to- $15 \mathrm{C}$. Plant temperatures were recorded at 60 -sec intervals. Freezing temperatures were detected graphically as exotherms by computer-assisted thermal analysis. After thawing, strawberry plants were homogenized in $180 \mathrm{ml}$ sterile, deionized water, concentrated by centrifugation, and dilutionplated on nutrient agar with and without rifampicin to count populations of INA and total bacteria, respectively (Anderson et al., 1987). Bacterial cells from control plants were assayed by the plate-harvesting technique (Anderson and Ashworth, 1985) to check for INA bacterial contamination. Although this procedure provides only order-of-magnitude estimates of the numbers of INA bacteria, it was chosen because of its capacity to detect low populations of INA bacteria. Two plants in each of the four treatments [control (distilled water), Frostgard (10\% by volume), INA bacteria $\left(10^{6} \mathrm{cell} / \mathrm{s} / \mathrm{ml}\right)$, and INA bacteria $\left(10^{6}\right.$ cells $/ \mathrm{ml})+$ Frostgard ( $10 \%$ by volume)] were assayed on eight dates. Data from three additional repetitions of the experiment were not presented due to natural INA bacterial contamination. The effects of Frostgard were similar to those in experiments in which only inoculated INA bacteria were detected. Strawberry plants used to study ice-propagation rates were handled similarly to those described above, except no INA bacteria or Frostgard was applied. Thermocouples were attached to all leaves, petioles, flower pedicels, and crowns, and temperature data were recorded at $15-\mathrm{sec}$ intervals.

Freezing detached strawberry leaves. Additional studies were conducted to determine whether the cryoprotective action of Frostgard could be improved by facilitating its uptake. Individual leaves were detached, submerged in solutions of $0 \%$ to $20 \%$ Frostgard plus $0.01 \%$ (by volume) of the surfactant polyoxyethylenesorbitan (Tween 20), and vacuuminfiltrated for $5 \mathrm{~min}$. After slowly equilibrating to atmospheric pressure, leaves were blotted dry and cooled in test tubes placed in a refrigerated bath for measuring freezing tem- peratures. Three leaves per concentration were assayed on each of three dates. Data were analyzed using the general linear models procedure (SAS Institute, 1985). In whole-plant studies, treatments were compared within each plant part (crown, petiole, pedicel). Trend analysis was used to determine the effect of Frostgard in studies using a concentration series.

Frostgard effectively reduced freezing temperatures of aqueous solutions (Table 1). Although the relationship was weak $\left(r^{2}=0.51\right)$, freezing temperature was related linearly to Frostgard concentrations from $0 \%$ to $20 \%$. The reduction was larger than expected based on osmotic potentials of the solutions (data not presented). Supercooling and melting point depression from solutes are additive processes (Burke and Stushnoff, 1976). Linear freezing rates of solutions in pipettes were $\approx 100$-fold less with $20 \%$ Frostgard compared to distilled water. Lusena (1955) reported decreasing freezing rates with increasing sucrose and ethanol concentrations. Freezing temperatures of detached strawberry leaves vacuum-infiltrated with Frostgard from 0\% to 20\% exhibited a negative linear relationship with concentration (Table 1). Leaves infiltrated with $0.1 \%$ or $1 \%$ Frostgard exhibited freezing behavior similar to that of the controls, but leaves infiltrated with $20 \%$ Frostgard supercooled

Table 1. Effects of Frostgard at various concentrations (percentage by volume) on freezing temperatures and rates of aqueous solutions and freezing temperatures of infiltrated strawberry leaves. Freezing temperatures were determined by cooling test tubes containing $3 \mathrm{ml}$ of Frostgard solutions or detached leaves in a refrigerated bath. Freezing rates were measured by detecting the linear rate of ice propagation in solutions in pipettes in a freezer at $-3.5 \pm 1.1 \mathrm{C}$. Values are means \pm SD of 60 solution freezing temperatures, 9 solution freezing rates, and 9 leaf freezing temperatures.

\begin{tabular}{|c|c|c|c|}
\hline \multirow[b]{3}{*}{$\begin{array}{l}\text { Frostgard } \\
\text { (\% by vol) }\end{array}$} & \multicolumn{3}{|c|}{ Mean \pm SD } \\
\hline & \multicolumn{2}{|c|}{$\begin{array}{l}\text { Frostgard } \\
\text { solutions }\end{array}$} & \multirow{2}{*}{$\begin{array}{l}\text { Detached } \\
\text { leaves } \\
\text { Freezing } \\
\text { temp }\left({ }^{\circ} \mathrm{C}\right)\end{array}$} \\
\hline & $\begin{array}{l}\text { Freezing } \\
\text { temp }\left({ }^{\circ} \mathrm{C}\right)\end{array}$ & $\begin{array}{c}\text { Rate } \\
\left(\mathrm{cm} \cdot \mathrm{min}^{-1}\right) \\
\end{array}$ & \\
\hline o & $-10.0 \pm 0.5$ & $54.3 \pm 9.9$ & $-4.9 \pm 0.8$ \\
\hline 0.1 & $-14.2 \pm 2.8$ & $46.7 \pm 11.8$ & $-4.7 \pm 1.0$ \\
\hline 1.0 & $-13.7 \pm 2.5$ & $37.5 \pm 11.4$ & $-4.7 \pm 0.8$ \\
\hline 5.0 & $-14.6 \pm 2.4$ & $18.2 \pm 14.4$ & $-5.4 \pm 0.9$ \\
\hline 10.0 & $-15.6 \pm 2.4$ & $4.2 \pm 2.4$ & $-6.0 \pm 1.0$ \\
\hline 20.0 & $-18.1 \pm 2.4$ & $0.4 \pm 0.2$ & $-6.6 \pm 0.8$ \\
\hline \multicolumn{4}{|l|}{ Significance } \\
\hline Linear & $*$ & $* *$ & $*$ \\
\hline Quadratic & NS & $*$ & NS \\
\hline Cubic & NS & NS & NS \\
\hline
\end{tabular}

${ }_{\mathrm{NS},{ }^{*, *}}$ Nonsignificant or significant at $P \leq 0.05$ or 0.01 , respectively.

Table 2. Freezing temperatures of strawberry plants sprayed with distilled water (control); Frostgard (10\% by volume); Erwinia herbicola, an ice-nucleation-active (INA) bacteria, at $10^{6}$ cells $/ \mathrm{ml}$; or Frostgard and INA bacteria. Plants were sprayed with Frostgard $24 \mathrm{~h}$ after bacterial inoculation and $48 \mathrm{~h}$ before freezing assays.

\begin{tabular}{lccc}
\hline & & Freezing temp $\left({ }^{\circ} \mathrm{C}\right)$ & \\
\cline { 2 - 4 } & & Leaf & Flower \\
Treatment & Crown & petiole & pedicel \\
\hline Control & $-2.8 \pm 0.5$ & $-5.1 \pm 0.7$ & $-6.1 \pm 1.0$ \\
Frostgard (FG) & $-3.4 \pm 1.4$ & $-5.4 \pm 1.0$ & $-6.1 \pm 0.9$ \\
INA & $-3.2 \pm 1.1$ & $-4.8 \pm 1.2$ & $-4.2 \pm 1.6$ \\
INA + FG & $-3.0 \pm 0.8$ & $-4.4 \pm 1.2$ & $-4.4 \pm 1.8$ \\
Significance & NS & NS & NS \\
$\quad$ FG & NS & NS & NS \\
INA & NS & NS & NS \\
FG $\times$ INA & &
\end{tabular}


tected, other aerial structures (leaf blades, petioles, flower pedicels) ranged from -2.7 to 4.3C. Crown and soil temperatures were 0.5 and 7.0C, respectively. The last of four leaves on this plant to freeze supercooled to $-5.0 \mathrm{C}$ before freezing $112 \mathrm{~min}$ after the first leaf froze. The crown froze at $-2.6 \mathrm{C}, 193 \mathrm{~min}$ after freezing was first detected. However, crown temperature was not always $>0 \mathrm{C}$ when other tissues froze, a result suggesting that other barriers may be present. However, if any leaves supercooled when the crown froze, leaf freezing was observed within $15 \mathrm{sec}$. Leaves and flowers seemed to freeze independently, often over the span of $>1 \mathrm{~h}$.

The effects of freezing on cell viability vary with tissue and acclimation stage. Vegetative tissues such as crowns can acclimate to tolerate freezing (Boyce and Smith, 1967). Detached strawberry flowers were killed near the freezing temperature of about $-5 \mathrm{C}$ ( $\mathrm{Ki}$ and Warmund, 1992). In a study with detached flowers that were seeded with ice to prevent supercooling, median killing temperatures ranged from $-1.6 \mathrm{C}$ in early September to 3.4C in late October in Vermont (Boyce and Marini, 1978). Although we did not try to evaluate injury resulting from freezing in our study, it is likely that flowers were susceptible to freezing injury.

Aqueous Frostgard solutions exhibited slower freezing rates and increased supercooling as the concentration increased from $0 \%$ to $20 \%$. Although supercooling of detached leaves increased with Frostgard, Frostgard did not effectively promote supercooling of intact strawberry plants in the presence or absence of INA bacteria in laboratory experiments. However, the efficacy of Frostgard may be greater in the field or under other experimental conditions. For example, the supercooling of grape (Vitis labruscana Bailey) leaf disks increased $2.1 \mathrm{C}$ by a $1 \%$ (by volume) Frostgard spray (Himelrick et al., 1991).

\section{Literature Cited}

Anderson, J.A. and E.N. Ashworth. 1985. Ice nucleation in tomato plants. J. Amer. Soc. Hort. Sci. 110:291-296.

Anderson, J.A. and M.W. Smith. 1989. Ice propagation in peach shoots and flowers. HortScience 24:480-482.
Anderson, J. A., E.N. Ashworth, and G.A. Davis. 1987. Nonbacterial ice nucleation in peach shoots. J. Amer. Soc. Hort. Sci. 112:215-218.

Anderson, J.A., D.W. Buchanan, R.E. Stall, and C.B. Hall. 1982. Frost injury of tender plants increased by Pseudomonas syringae van Hall. J. Amer. Soc. Hort. Sci. 107:123-125.

Ashworth, E. N., J.A. Anderson, G.A. Davis, and G.W. Lightner. 1985. Ice formation in Prunus persica under field conditions. J. Amer. Soc. Hort. Sci. 110:322-324.

Boyce, B.R. and R.P. Marini. 1978. Cold acclimation of everbearing strawberry blossoms. HortScience 13:543-544.

Boyce, B.R. and C.R. Smith. 1967. Low temperature crown injury of dormant 'Catskill' strawberries. J. Amer. Soc. Hort. Sci. 91:261-266.

Buchanan, D. W., F.S. Davies, and D.S. Harrison. 1982. High and low volume under-tree, irrigation for citrus cold protection. Proc. Fla. State Hort Soc. 95:23-26.

Burke, M.J. and C. Stushnoff. 1976. Frost hardiness: A discussion of possible molecular causes of injury with particular reference to supercooling of water, p. 197-225. In: H. Mussell and R.C. Staples (eds.). Stress physiology in crop plants. Wiley, N.Y.

Himelrick, D.G., R.M. Pool, and P.J. McInnis. 1991. Cryoprotectants influence freezing resistance of grapevine bud and leaf tissue. HostScience 26:406-407.

Hirano, S. S., L.S. Baker, and C.D. Upper. 1985. Ice nucleation temperature of individual leaves in relation to population sizes of ice nucleation active bacteria and frost injury. Plant Physiol. 77:259-265.

Hummel, R.L. and T.M. Teets. 1986. Effect of an antitranspirant, a foliar nutrient spray, and a cryoprotective polymer on supercooling and ice nucleation active bacteria in Hibiscus rosasinensis and Lycopersicon esculentum. Proc. Fla. State Hort. Soc. 99:256-257.

Ki, W.K. and M.R. Warmund. 1992. Low-temperature injury to strawberry floral organs at several stages of development. HortScience 27: 1302 1304.

Lindemann, J. and T.V. Suslow. 1987. Competition between ice nucleation-active wild type and ice nucleation-deficient deletion mutant strains of Pseudomonas syringae and $P$. fluorescens biovru I and biological control of frost injury on strawberry blossoms. Phytopathology 77:882-886.

Lindow, S.E. 1983a. Methods of preventing frost injury caused by epiphytic ice-nucleation-active bacteria. Plant Dis. 67:327-333.

Lindow, S.E. 1983b. The role of bacterial ice nucleation in frost injury to plants. Annu. Rev. Phytopathol. 21:363-384.

Lindow, S.E., D.C. Amy, and C.D. Upper. 1978a.
Erwinia herbicola A bacterial ice nucleus active in increasing frost injury to corn. Phytopathology 68:523-527.

Lindow, S.E., D.C. Amy, C.D. Upper, and W.R. Barchet. 1978b. The role of bacterial ice nuclei in frost injury to sensitive plants, p. 249-263. h. P.H. Li and A. Sakai (eds.). Plant cold hardiness and freezing stress. Academic, New York.

Locascio, S.J., D.S. Harrison, and V.F. Nettles. 1967. Sprinkler irrigation of strawberries for freeze protection. Proc. Fla. State Hort. Soc. 80:208-211.

Lusena, C.V. 1955. Ice propagation in systems of biological interest. III. Effect of solutes on ice nucleation and growth of ice crystals. Arch. Biochem. Biophys. 57:277-284

Maki, L.R., E.L. Galyan, M. Chang-Chien, and D.R. Caldwell. 1974. Ice nucleation induced by Pseudomonas syringae. Applied Microbiol. 28:456-459.

Parsons, L.R. and D.P.H. Tucker. 1984. Sprinkler irrigation for cold protection in citrus groves and nurseries during an advective freeze. Proc. Fl. State Hort. Soc 97:28-30.

Pardin, J.P. and J. Luisetti. 1978. Ice nucleation activity among phytopathogenic bacteria, p. 725731. In Station de pathologic Vegetale et Phytobacteriology (ed.). Proc. Fourth Intl. Conf. Plant Pathogenic Bacteria. vol. 2. Inst. Natl. Recherche Agronomique, Beaucouze, France.

Perry, K. B., A.R. Bonanno, and D.W. Monks. 1992. Two putative cryoprotectants do not provide frost and freeze protection in tomato and pepper. HortScience 27:26-27.

Proebsting, Jr., E.L., P.K. Andrews, and D.C. Gross. 1982. Supercooling young developing fruit and floral buds in deciduous orchards. HortScience 17:67-68.

Rieger, M. and G. Krewer. 1988. Cryoprotectant and antitranspirant efficacy for frost protection of Prunus flower ovaries. Proc. Fla. State Hort. Soc. 101:251-253.

SAS Institute. 1985. SAS/STAT guide for personal computers. version 6. SAS Institute, Cary, N.C.

White, G.F. and J.E. Haas. 1975. Assessment of research on natural hazards. MIT Press, Cambridge, Mass.

Wilcox, D. and F.S. Davies. 1981. Modification of air temperature and citrus leaf temperature with high volume under-tree sprinklers. Proc. Fla. State Hort. Soc. 94:59-63.

Yelenosky, G. 1991. Apparent nucleation and freezing in various parts of young citrus trees during controlled freezes. HortScience 26:576-579.

Yelenosky, G. and G. Horanic. 1969. Subcooling in wood of citrus seedlings. Cryobiology 5:281283.

Yelenosky, G. and R. Young. 1981. Citrus freeze problems in Florida. Citrus Ind. Msg. 62:7-11. 